\title{
THE EFFECT OF BEEF TALLOW IN LAMB NUTRITION ON FATTENING AND CARCASS CHARACTERISTICS
}

\author{
D. Ružić-Muslić, M. P. Petrović, Z. Bijelić \\ Institute for Animal Husbandry, 11080, Belgrade-Zemun, Republic of Serbia \\ Corresponding author: draganamuslic@yahoo.co.uk \\ Invited paper
}

Abstract: Trial was carried out on 60 suckling lambs of Mis sheep population, divided into three groups. Beside milk, lambs consumed alfalfa hay and iso-protein concentrate mixtures $(15 \% \mathrm{CP})$ ad libitum. Forage mixture I was of standard composition, whereas mixtures II and III contained 4 and $6 \%$ of beef tallow, respectively. Energy value of used mixtures I, II and III was 7,29, 7,71 and 7,94 MJ, respectively. Fattening duration was 60 days. Statistical processing of obtained data was performed using standard mathematical-statistical methods. Lambs on treatments I:II:III realized average daily gain of: $0,280: 0,303: 0,277 \mathrm{~kg}$. Conversion of dry matter of diet was: 2,68: 2,58: $2,93 \mathrm{~kg}$; of energy: 19,08 : 18,37 : 20,71 MJ NEM; of protein: $481: 451: 514 \mathrm{~g}$. Values of the meat yield of warm carcass were: $57,89: 58,63: 58,46 \%$. The best production results in regard to gain, and feed conversion were realized by lambs on treatment with $4 \%$ of beef tallow in the mixtures.

Key words: lambs, beef tallow, daily gain, conversion, meat yield/dressing percentage

\section{Introduction}

Production of lamb meat is of greatest economical importance in sheep production. Body weight of lamb is determined by series of genetic and paragenetic factors, such as: breed, type, age and sex of animal, housing conditions and environment (Morris et al., 2000;, Petrović, 2000, 2006; Hansen and Shrestha, 2002; Zapasnikiene, 2002; Hansen and Shrestha, 2002; Notter et al., 2005). Nutrition as factor of environment has central role (Santos et al., 2002; RužićMuslić, 2006), since it enables for production potential of the head to be expressed. Intensive fattening of lambs demands monitoring of series of important issues, 
most important one is issue of the diet concentration (Diaz et al., 2002; Samy, 2006; Ružić-Muslić et al., 2007).

Because of the small volume of digestive organs of lambs on one side and greater intensity of growth on the other, and in order to secure optimal diet concentrations, some unconventional feeds are used, such as fats of animal origin (beef or pork fat). There are several reasons for adding of fat into diets for ruminants, as stated by Steele (1985): energy density of diet is increased, essential fatty acids are provided, transport of liposoluble vitamins assisted, taste of diet is improved, diets are not so much dusty and pelleting of food is easier. Besides, researchers in Great Britain have proven that by $4-6 \%$ of added fat in ruminants' diets $34-45 \%$ less methane is produced in stomach which can save $2-5 \%$ of energy, reducing the cost of fattening.

Objective of this paper was to investigate the effect of concentration of diet on fattening characteristics of lambs.

\section{Materials and Methods}

Research was carried out on experimental sheep farm of the Institute for Animal Husbandry, Belgrade-Zemun. Lambs of Mis sheep population were used in this investigation. Trial included 60 suckling lambs divided into three groups, equal in regard to age, body mass, presence of single lambs, twin and triplet lambs. Average body mass of lams at the beginning of trial was approx. $15 \mathrm{~kg}$ and at the end of trial approx. $30 \mathrm{~kg}$.

Table 1. Structure of concentrate mix, $\%$

\begin{tabular}{|l|c|c|c|}
\hline \multirow{2}{*}{ F e e d s } & \multicolumn{3}{|c|}{ L a m b g ro u p s } \\
\hline & I & II & III \\
\hline Corn chop & 66.3 & 61.3 & 58.3 \\
\hline Sunflower meal & 30 & 31 & 32 \\
\hline Tallow & 0 & 4 & 6 \\
\hline Chalk & 2 & 2 & 2 \\
\hline Iodised salt & 0.7 & 0.7 & 0.7 \\
\hline Premix & 1 & 1 & 100 \\
\hline Total & 100 & 100 & 1 \\
\hline
\end{tabular}

Nutrition of lambs with forage mixtures and alfalfa hay was ad libitum. Prepared mixtures were different in regard to energy content. Namely, mixture I was of standard composition, whereas mixtures II and III contained 4 and $6 \%$ of tallow, respectively. Concentration of used mixtures in following order I: II: III 
was: $1.23: 1.30: 1.34$ FU. Administered food and remains were measured regularly, recorded and analyzed using usual chemical procedure - WEENDE.

Table 2. Nutritive value of feeds used in trial

\begin{tabular}{|l|c|c|c|}
\hline Feeds & FU & NEM/NME, MJ & $\begin{array}{c}\text { Undegradable } \\
\text { protein, } \%\end{array}$ \\
\hline Concentrate I & 1.23 & 7.29 & 0.38 \\
\hline Concentrate II & 1.30 & 7.71 & 0.37 \\
\hline Concentrate III & 1.34 & 7.94 & 0.37 \\
\hline Hay & 0.69 & 4.10 & 0.28 \\
\hline Milk & 0.39 & 2.32 & 0.70 \\
\hline
\end{tabular}

At the end of trial, in order to determine yield and quality of meat, by method of random sample, 4 male and 4 female lambs were taken from each group. After slaughtering and primary processing which were carried out in usual way in slaughterhouse of the Institute for Animal husbandry, following parameters were determined: mass of lambs prior to slaughtering and mass of warm carcass with intestines. After $24 \mathrm{~h}$ cooling period on temperature from $2-4^{0} \mathrm{C}$, dissection of carcasses was carried out producing two symmetrical carcass sides. Left carcass side was cut on main parts according to method determined by Regulation on cutting and categorization of sheep and lamb meat (Sl. list SFRJ/Official journal of SFRY, 34/74).

Statistical processing of obtained results was carried out on PC, using variance analysis.

\section{Results and Discussion} in Table 3.

Data on average fattening indicators according to treatments are presented

Table 3. Performance of fattening lambs

\begin{tabular}{|l|c|c|c|}
\hline \multirow{2}{*}{ C rite ri o n } & \multicolumn{3}{|c|}{ F e e d in g tr e a t m e n t s } \\
\hline & I & II & III \\
\hline Initial body mass,kg & 14.97 & 15.12 & 15.15 \\
\hline Initial age, $\mathrm{d}$ & 30 & 30 & 30 \\
\hline Final body mass, kg & 29.81 & 31.19 & 29.86 \\
\hline Total gain,kg & 14.84 & 16.07 & 14.71 \\
\hline Average daily gain, $\mathrm{g}$ & 280 & 303 & 270 \\
\hline
\end{tabular}

Body mass and gain: Average body mass of lambs at the beginning of trial was equal and varied from $14.97 \mathrm{~kg}$ (I) to $15.15 \mathrm{~kg}$ (III). After 60 days of fattening, 
at the end of trial, final body masses of lambs in different groups were also unified: $29.81 \mathrm{~kg}$ (I), 29.86kg (III) and 31.19kg (II). Considering these data, differences in energy value of used concentrate mixtures had no significant effect $(\mathrm{P}>0.05)$ on intensity of lamb growth. However, certain advantage can be attributed to the effect of nutrition on treatment II, considering that lambs from this group had the greatest final body mass. In regard to average daily gain, obtained results indicate that increase of concentration of II treatment diet lead to increase of daily gain by $7.59 \%$ compared to control group. Research results obtained by Negovanović et al. (1983), Osman et al. (1988), Novikov et al. (1986) and Šindarska (1987) confirm this tendency.

Namely, stated authors have established that level of body masses and average daily gains of lambs in fattening to some extent depended on energy value of used diet. Research carried out by Šindarska (1987) on lambs of Trakia thin fleece breed using isoprotein diets with different energy contents indicated that in the first fattening period $(13-25 \mathrm{~kg})$ increased energy content to some extent resulted in increase of daily gains.

Feed and nutrient consumption: Efficiency of feed utilization, expressed as feed consumption per unit of gain, shows that lambs of group II consumed least food per $\mathrm{kg}$ of achieved gain. In regard to dry matter conversion, it was observed that increase of energy content in mixture by adding of $4 \%$ of tallow implicated reduction of cost of consumption of dry matter by $3.73 \%$ compared to group I. However, further increase of concentration in diet III was followed by increase of dry matter consumption per unit of gain (by $11.9 \%$ compared to treatment II).

Table 4. Consumption of feed and nutrients per body weight gain unit, g/kg

\begin{tabular}{|l|c|c|c|}
\hline Feeds & \multicolumn{3}{|c|}{ Nutrition treatmens } \\
\hline & I & II & II \\
\hline Milk & 740 & 670 & 730 \\
\hline Concentrate mixture & 1850 & 1660 & 1800 \\
\hline Alfalfa hay & 1050 & 1130 & 2930 \\
\hline DM & 2680 & 2580 & 514 \\
\hline CP & 481 & 451 & 20.71 \\
\hline NEM,MJ/kg & 19.08 & 18.37 & \\
\hline
\end{tabular}

Investigations carried out by other authors confirm results obtained in this research. Namely Negovanović et al. (1983), Ely et al. (1988), Ilian et al. (1988), have established that increase of diet concentration resulted to some extent in reduction of dry matter consumption per unit of realized gain. 
Similar to changed in DM consumption per $\mathrm{kg}$ of gain, also total consumption of protein and energy changed. With increase of diet concentration by adding of $4 \%$ of tallow in forage mixture, tendency of decrease in energy and protein consumption per $\mathrm{kg}$ of gain was observed. Further increase of energy content in diet III resulted in insignificant increase of protein and energy consumption per unit of gain in trial lambs.

Similarity with our results can also be observed in research by Šindarska 1987. In investigation of the effect of isoprotein diets with different energy concentrations $(0.70-0.97 \mathrm{HJ})$ on lambs of Trakia thin fleece breed, author concluded that increase of energy value of diet caused reduction in protein consumption by $20.35 \%$ per $\mathrm{kg}$ of gain.

Slaughter results: Results of average values for mass and carcass dressing percentage of slaughtered lambs are presented in Table 5 .

Body masses prior to slaughtering in lambs on treatments I:II:III were: $30.56: 30.31: 30.00 \mathrm{~kg}$. Existing differences weren't statistically significant $(\mathrm{P}>0.05)$.

Table 5. Mean values for carcass mass and dressing percentage

\begin{tabular}{|l|c|c|c|c|c|c|}
\hline \multirow{2}{*}{ T r a i t s } & \multicolumn{6}{|c|}{ F e e d i n g t r e a t m e n t s } \\
\cline { 2 - 7 } & \multicolumn{2}{|c|}{$\mathrm{I}$} & \multicolumn{2}{|c|}{ II } & \multicolumn{2}{c|}{ III } \\
\cline { 2 - 7 } & $\mathrm{x}$ & $\mathrm{Sd}$ & $\mathrm{x}$ & $\mathrm{Sd}$ & $\mathrm{x}$ & $\mathrm{Sd}$ \\
\hline $\begin{array}{l}\text { Pre-slaughter } \\
\text { lamb mass,kg }\end{array}$ & 29.81 & 3.840 & 31.19 & 3.069. & 29.86 & 4.342 \\
\hline $\begin{array}{l}\text { Weight- hot carcass } \\
\text { with intestines, kg }\end{array}$ & 17.71 & 2.472 & 17.81 & 2.358 & 17.63 & 3.408 \\
\hline $\begin{array}{l}\text { Dressing percentage } \\
\text { of hot carcass } \\
\text { with intestines }\end{array}$ & 57.89 & 2.177 & 58.63 & 3.205 & 58.46 & 4.538 \\
\hline $\begin{array}{l}\text { Dressing percentage } \\
\text { of cold carcass } \\
\text { without intestines }\end{array}$ & 45.96 & 2.138 & 46.94 & 3.452 & 46.27 & 4.288 \\
\hline
\end{tabular}

Values of dressing percentage of hot carcass with intestines varied from 57.89 in lambs from group Ito $58.63 \%$ in lambs from group II. Determined differences varied in limits of random deviations $(\mathrm{P}>0.05)$. These investigations are similar by slaughter results citing other authors. Petrović (2006) states that the dressing percentage of hot carcass in lambs of Mis population is $58.96 \%$.In regard to influence of concentration of diet on value of dressing percentage it is evident that applied feeding treatment had no considerable effect on investigated trait. 


\section{Conclusion}

Based on obtained research results of the effect of diet concentration on fattening characteristics of lambs, following conclusions can be made:

Final body masses of lambs fed diets of different concentrations in average were: 29.81 (I), 31.19 (II) and $29.86 \mathrm{~kg}$ (III). Established differences varied within limits of random deviations $(\mathrm{P}>0.05)$.

II.

The greatest average daily gain $(0.303 \mathrm{~kg})$ was achieved by lambs fed diet

With increase of diet concentration by adding $4 \%$ of tallow in forage mixture, tendency of reduction of consumption of dry matter, energy and protein per $\mathrm{kg}$ of gain was observed.

Dressing percentage of warm carcass with intestines according to treatments was: 57.89 (I), 58.63\% (II) and 58.46\% (III).

Effect of concentration of diet on gain, feed efficiency, yield and quality of meat wasn't significant. The best results were realized in lambs fed diet of diet II (7.71 MJ NEM and $16 \%$ total protein).

\section{Acknowledgment}

This research is part of the Project TR- 20042 financial supported by Ministry of Science and Technological Development of the Republic Serbia.

\section{Uticaj goveđeg loja u ishrani jagnjadi na tovne i klanične karakteristike}

D. Ružić-Muslić, M. P. Petrović, Z. Bijelić

\section{Rezime}

Ogled je izveden na 60 neodbijene jagnjadi Mis populacije ovaca koji su bili podeljeni $\mathrm{u}$ tri grupe. Osim mleka, jagnjad su konzumirala seno lucerke i izoproteinske smeše koncentrata (15\% SP) ad libitum. Krmna smeša I je bila standardnog sastava, dok su smeše II i III sadržavale 4, odnosno $6 \%$ goveđeg loja. Energetska vrednost korišćenih smeša I, II i III je bila 7,29, 7,71 i 7,94 MJ, respektivno. Trajanje tova je bilo 60 dana. Statistička obrada podataka je urađena standardnim matematičko-statističkim metodama.

Jagnjad na tretmanima I:II:III su ostvarila prosečni dnevni prirast od 0,280 : 0,303 : 0,277 kg. Konverzija suve materije obroka je bila 2,68: 2,58: 2,93 kg, 
energije, 19,08: 18,37:20,71 MJ NEM, proteina, $481: 451: 514$ g. Vrednosti za prinos mesa u toplom trupu su bile 57,89: $58,63: 58,46 \%$.

Najbolje proizvodne rezultate u pogledu prirasta i konverzije hrane su ostvarila jagnjad na tretmanu sa $4 \%$ goveđeg loja u smešama.

\section{References}

DIAZ M.T., VELASCO S., CANEQUE V., LAUZURICA S., RUIZ DE HUIDOBRO F., PEREZ C., GONZALES J., MANZANARES C. (2002): Use of concentrate or pasture for fattening lambs and its effect on carcass and meat quality. Small Ruminant Res., 43, 257268.

ELY D.G., MUSEN S.L., RAGLAND K.K. (1988): Nutrient use by lambs supplemented with lipid coated protein. Progres. Rep. Univ. of Kentucky. College of agriculture. Agr. exsperiment. Station, 310. Kentucky.

HANSEN C., SHRESTHA J.N.B. (2002): Consistency of genetic parameters of productivity for ewes lambing in February, June, and October under an 8-month breeding management. Small Rum. Res., 44, 1-8.

ILIAN, M.A., RAZZAQUE, M.A., SALMAN, A.J. (1988): Use of fat in diets of sheep in hot environmentes.1. Effects on performance, carcass characteristics and lipid composition of plasma. Anim. Feed. sc. Technol., 19, 4, 327 - 341.

MORRIS, C.A., HICKEY S.M., CLARKE J.N. (2000): Genetic and environmental factors affecting lamb survival at birth and through to weaning. NZ. J. Agric. Res., $43,515-524$

NEGOVANOVIĆ D., PAVLIČEVIĆ A., JUZBAŠIĆ N. (1983): Uticaj nivoa i međusobnog odnosa energije i proteina na svarljivost obroka i proizvodne rezultate u tovu jagnjadi. Zbornik radova Poljoprivrednog fakulteta, 27 - 30, 587, 53-62, Beograd.

NOTTER D.R., BORG R.C., KUEHN L.A. (2005): Adjustment of lamb birth and weaning weights for continuous effects of ewe age. Anim. Sci., 80, 241-249.

NOVIKOV L.S., SAKSONOV T.A., IVANOVA L.S. (1986): Intensive growing of Romanov lambs. Naučno - proizvodstvenaja konferencija po ovcevodstvu i kozovodstvu: Tezis naučnih sobšćenii. Č.2.1986. 160-161. Stavropolj. 22-23. 04. 1986., 87-3833.

OSMAN A.G., EL TAYEB A.E., SULEIMAN A.H., MOHAMED T.A.(1988): The effect of feeding sorghum fodder, urea and blood meal on productivity of growing lambs. Anim. Feed. Sc. Technol., 19. 4, 351-358.

PETROVIĆ P.M (2000): Genetic and improvement of sheep. Naucna, Belgrade, 365pp.

PETROVIĆ P.M. (1992): Investigation of reproductive and productive traits of Württemberg breed of sheep (Merino landschaf). Doctoral dissertation, University of Belgrade. 
PETROVIĆ P.M. (2006): Creation of meaty sheep breed. Mis sheep. Institute for Animal Husbandry, Belgrade, 43 pp.

RUŽIĆ D. (1997): Uticaj nivoa energije na svarljivost obroka i proizvodne rezultate lagnjadi u tovu. Magistarska teza. Poljoprivredni fakultet, Beograd.

RUŽIĆ-MUSLIĆ D. (2006): Effect of different source of protein in meal on production results of fattening lambs. Doctoral dissertation, University of Belgrade. RUŽIĆ D., GRUBIĆ G., PETROVIĆ P.M., NEGOVANOVIĆ D., NEŠIĆ Z., PERISIC P., ZUJOVIC M. (2007): The effect of the level of non degradable protein on digestibility of nutritive substances in fattening lambs. Biotechnology in Animal Husbandry, 23, 5-6, 131-137.

SAMY M.H. (2006): Effect of pre-weaning diet and age performance of lambs weaned at six and nine weeks at weaning on lambs rumen development. Ph.D.Thesis Department of Animal Production, Faculty of Agriculture, Al-Azhar University.

SANTOS-SILVA J., MENDES I.A., BESSA R.J.B. (2002): The effect of genotype, feeding system and slaughter weight on the quality of light lambs. 1. Growth, carcass composition and meat quality. Livest. Prod. Sci., 76, 17-25.

ŠINDARSKA Z. (1987): Vlijanije na energoproteinovoto sotnošenije na datbata vrhu otlaganeto na maznini i protein $\mathrm{v}$ trupa na ugojavani agneta. Životnovodni nauki, XXIV, 10, 44-50.

STEELE W. (1985): The role fats and oils in the nutrition of ruminants. NRANational Renderers Association, 33-39.

ZAPASNIKIENE B. (2002): The effect of age of ewes and lambing season on litter size and weight of lambs. Veterinaria ir zootechnika, 19, 41, 112-115. 